\title{
Participation of second home owners and permanent residents in local decision making: the case of a rural village in Finland
}

\author{
ASTA KIETÄVÄINEN, JANNE RINNE, RIIKKA PALONIEMI AND SEIJA TUULENTIE
}

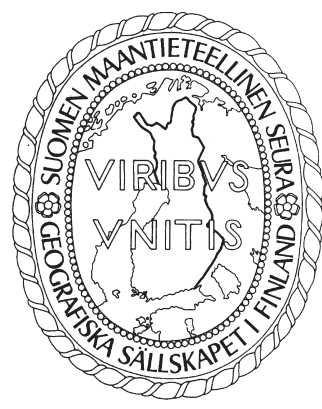

Kietäväinen, Asta, Janne Rinne, Riikka Paloniemi \& Seija Tuulentie (2016). Participation of second home owners and permanent residents in local decision making: the case of a rural village in Finland. Fennia 194: 2, 152-167. ISSN $1798-5617$.

In Finland, there are almost 500,000 second homes and in some areas the number of second home owners exceeds that of permanent residents. Currently, second home owners are also spending more time in their second homes. If second home owners are not permanent residents, administration may exclude them from local institutions, and treat second home owners as only partial members of the community. It has been stated that municipal decision making and the role of the municipality as an actor in the local community should be broadened in order to strengthen democracy and the participation of its residents as a core of municipal self-administration. Hence, participating in communal decision making is mainly possible only for permanent residents. The issue is whether it is possible to change this situation via the municipalities' own reforms and state regulations. New municipal administration experiments have recently emerged in Finland. Here we study how the new local administrative model, the Communal District Committee, has affected local participation and local governance in a rural areas by exploring second home owners' opportunities to participate in local decision making and development processes. The data consists of documents, focus group discussions and a questionnaire. We used qualitative and quantitative methods in the data analysis. We found, on one hand, that permanent residents of villages recognise second home owners' hesitation to participate in local issues requiring planning and decision making. On the other hand, local-level communal decision making does not promote the participation of second home residents. On the basis of the findings of the study, we suggest that the municipal authorities should recognise the existence and importance of second home owners in the area, acknowledge them better in municipal plans and strategies, and offer them more resources and means to participate.

Keywords: communal governance, development, Finland, participation, rural area, second home owners

Asta Kietäväinen, Arctic Centre, University of Lapland, POB 122, Fl-96101 Rovaniemi, Finland. E-mail: asta.kietavainen@ulapland.fi

Janne Rinne \& Riikka Paloniemi, Environmental Policy Center, Finnish Environment Institute, (SYKE), POX 140, 00251 Helsinki, Finland. E-mail: janne.rinne@ ymparisto.fi \& riikka.paloniemi@ymparisto.fi

Seija Tuulentie, Natural Resources Institute Finland (Luke), Eteläranta 55, 96300

Rovaniemi, Finland. E-mail: seija.tuulentie@luke.fi

\section{Introduction}

Second home tourism is an essential component of peoples' housing and mobility in modern society (Hall \& Müller 2004). Especially in the Nordic countries, second home owners are a remarkable group spending time in the countryside (Hall et al. 2009; Farstad 2013). For example, in 2012 there were about 496,200 vacation homes in Finland (OSF 2012) alone. Second homes are often situ- 
ated in rural areas which are currently facing rapid changes in rural population structure due to the aging phenomenon as young people are moving to towns contributing to urbanisation. This pushes many rural municipalities, especially those that are small and medium-sized, into a vicious cycle of negative effects. For example, depopulation and increasing dependency ratio may crucially weaken the ability of municipalities to offer their citizens the basic services required by law (Kauppinen 2004).

Municipalities that have many second homes consider second home owners as a source of revitalisation for the communal economy, and providers of income for local enterprises, which helps to maintain public services in less populated areas in Finland (Rinne et al. 2015). The same phenomenon has been observed in other countries. Second home owners are also valued for their diverse know-how and contacts that are beneficial in developing rural areas (Müller 2006; Nylander \& Leppänen 2006; Marjavaara 2007; Müller \& Marjavaara 2012; Nordin \& Marjavaara 2012; de Nazaré Oliveira Roca et al. 2014; Rinne et al. 2014; Robertsson \& Marjavaara 2015). Yet the scope and content of economic impacts vary between countries and between regions within each country (Rye 2011; Barnett 2014).

Considering the scale of the second home phenomenon, a variety of issues need to be managed and governed in municipalities where there are considerable numbers of second homes. For example, seasonal fluctuations have impacts on the environmental, economic and social dynamics of these communities, leading in some case to conflicts over natural resource usage and other development-related issues (Hiltunen 2007; Kaltenborn et al. 2008; Kelly \& Hosking 2008; Overåg \& Berg 2011; Farstad \& Rye 2013; Hiltunen et al. 2013). Second homes are governed through various administrative sectors, jurisdictions, and policies. When policy integration in Finland was studied by Rinne et al. (2014) it was found that tourism and first homes were visible in many documents, whereas second homes were in many cases absent or mentioned only indirectly as a part of tourism or housing in general.

In many cases, the administration and related practices are based on the permanent residence of a person (Paris 2008; Hall 2015). If second home owners are not permanent residents, the administration may exclude them from local institutions, and treat second home owners as only partial members of the community (Hall \& Müller 2004; Marjavaara 2008; van Laar et al. 2014). For instance, second home owners are not allowed to vote in communal elections and they cannot be elected as decision-makers or formal representatives in municipal administrations. However, they may be stakeholders in land use planning, give statements on plans and have the right to appeal decisions (Nylander \& Leppänen 2006; Rinne et al. 2015). Second home owners pay real estate tax, and they are entitled to certain public services such as health care, planning permissions, libraries and rescue and fire services.

The idea of the community gaining ground in policymaking has been implemented in areas of services provision, education, policing, transport, regional development, primary industry, and local government (Adams \& Hess 2001). The main findings of Salminen (2008) show that the new governance is less hierarchical, more flexible and the service provision is redefined in terms of the interplay between state, municipalities and private- and third-sector actors. Participatory governance is based on the interactions of a socio-political system involving the public, private and civil sectors (Reddel 2002; Reddel \& Woolcock 2004). Citizens are regarded as active participants in their communities and aim to integrate their knowledge into policy processes (Hess \& Adams 2007). The most important relationship is not between different levels of government, but between government and people (Goss 2001). However, Sullivan et al. (2004) have argued that localities' capacities to act in their own interests are supported by the opportunities presented in a multi-level governance environment.

It has been stated that municipal decision making and the role of the municipality as an actor in the local community should be broadened (Ryynänen \& Uoti 2009). This enables strengthening of democracy and the participation of its residents as a core of municipal self-administration (Bifulco \& Centemeri 2008; Haveri et al. 2011). Participation is one of the current trend concepts that informs policy making and administrative practices in Finland and in other Western democracies (Kallio \& Bäcklund 2012). In these new forms of governance the residents' opportunities to influence policies and opportunities to participate are thus improved (Möttönen 2011). Direct citizen participation is often more feasible at the local level than the regional or national level, and as such is more common in a community context (Jordan et al. 2013). The flat management system associated 
with small councils brings decision makers into direct contact with community members (Dollery \& Johnson 2005). These direct methods of participation can both complement and revitalise a representative democracy (Sjöblom 2002).

Municipalities play a central role in local governance in Finland. In the Constitution of Finland (Ministry of Justice 1999), the country is divided into 317 municipalities (Suomen Kuntaliitto 2016) whose administration is based on the self-government of their residents. According to the Local Government Act (Ministry of Finance 1995), the aim of municipalities is to promote the welfare of residents and the sustainable development of the municipality (Asikainen 2011). Municipalities must arrange public services for residents either alone or in cooperation with other municipalities by providing the services themselves or by buying them from the private or a third sector. Halme and Kuukasjärvi (2010) have studied means and forms to extend decision making to a local level in cases where municipalities are merged in order to ensure the participation of local people. They suggest that issues suitable for local decision making are local services, sport and recreation facilities and subsidies for associations. In an attempt to bring decision making down to the "grassroots level", certain municipalities in Finland, such as Jyväskylä, Rovaniemi and Sonkajärvi, have set up Communal District Committees (CDC) (Aluelautakunta) (Pihlaja \& Sanberg 2012). The idea of this administrative experiment is to promote the development of communal services in remote rural areas. The official objective of the Committees is to enhance the provision of local services and the common development of the local district. Committees make decisions within the budget given by the municipal council. The committees should also enhance local people's participation in planning and decision-making.

In this paper, we analyse the ways in which the CDC model facilitates local participation and local governance in a rural area by focusing on the participation of both second home owners and permanent residents in current local decision making and development processes. We ask, how does this new administrative model enhance participation by the residents, part-time and permanent, of rural areas? We are also interested in who are the people involved in decision-making as well as how are different rural residents and their interests in local services and activities represented in municipal decision-making?

\section{Material and methods}

\section{Case study area}

Rovaniemi is one of the municipalities piloting the local CDC. Rovaniemi consists of an urban area and a sparsely populated rural area. Recently, in 2006, the rural commune of Rovaniemi was merged into Rovaniemi. In the newly formed Rovaniemi, only a few representatives of the former rural commune of Rovaniemi are represented in the municipal council of Rovaniemi. The local CDC follows the idea of community governance by enhancing local people's participation in local decision making. This refills possible participation gaps left by municipal elections.

Currently, Rovaniemi has six official CDCs. Our case study area is the village of Perunkajärvi, which is represented in the CDC of Sodankyläntie (Fig. 1). This Committee has formal representatives from nine villages such as Vikajärvi, Misi, and Alanampa. It is required that formal representatives must have their permanent residence in the village they represent. Hence, second home owners cannot be elected as formal representatives of the CDC, but they can participate as representatives in the parents organisation of villages, called RovaTokka in Rovaniemi. This is mainly an advising and coordinating organisation, and applies for funding for the development of local projects.

Almost all villages of the district have more second homes than permanent homes (Fig. 2). In Perunkajärvi, the second home owners are mainly members of the municipality, as they usually live closer to the city centre of Rovaniemi. Less than $20 \%$ of cottage owners have their permanent address outside Rovaniemi municipality.

We selected Perunkajärvi as a case study area because of the population structure. In particular, there are only a few permanent residents and most villagers are elderly people (Rovaniemi 2016). There are five times more second homes than permanent residences. Only a few services are provided in Perunkajärvi, some of them are private such as ploughing the roads in the winter and selling firewood. The provision of public services consists of, for example, in-home nursing and a mobile library.

In several Finnish municipalities, residents' associations and second home committees have been established in order to engage second home owners in local issues such as local development 

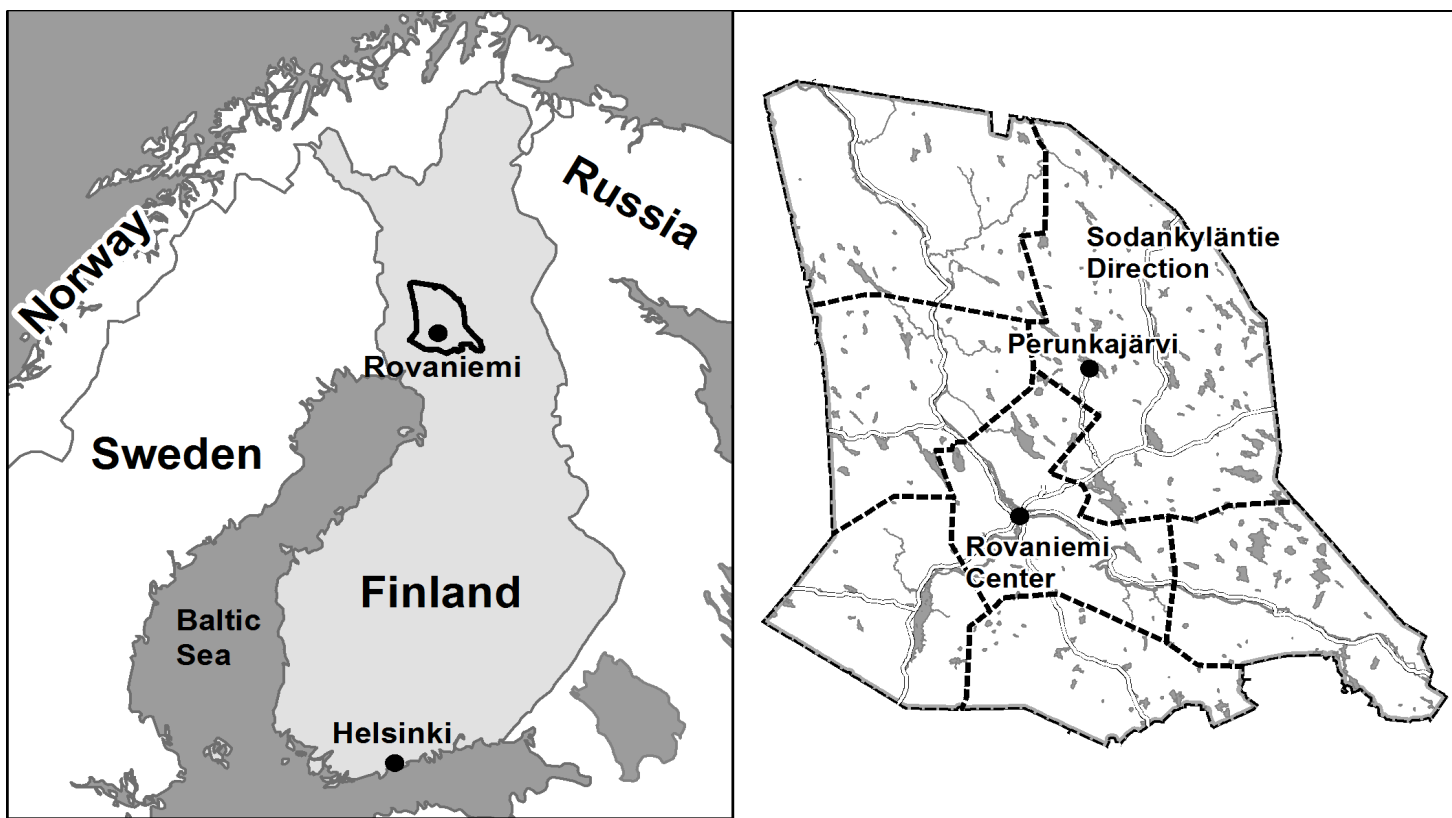

Fig. 1. The area of the Communal District Committee of Sodankyläntie in Rovaniemi.

and outdoor activities. The associations may provide a formal means of having an influence (Rinne et al. 2015). In fact, in Perunkajärvi, there is no second home committee, but there is a village association that aims to enhance local development and residents' well-being. The second home owners can be members of the village association, as well as members of other civic organisations and associations that are active in the village (Table 1).

The second home owners with their permanent address in the Rovaniemi municipality are more influential institutionally compared to other second home owners. In fact, they can be nominated for the city council or other official municipal bodies. The village association can nominate one representative for the $C D C$, but the representative ought to be a permanent resident of the village. The CDCs are in charge of making administrative decisions on facilities in rural areas, and are thus an official part of the municipal decision making structure (Fig 3).

The city council adjudicates the budgets of district committees and allocates the tasks that committees should manage and make decisions on. The committees have meetings seven to ten times per year. In addition to official decisions, the committees make statements about strategies and plans under preparation in the city council and propose to the city council ways to develop villages. On the one hand, the committee has to take into account municipal strategies and plans and, on the other hand, acquires information from the residents of the area about local needs for services.

\section{Materials}

We combine three types of materials in our study: planning, strategy and proceedings documents, a focus group interview in Perunkajärvi and a semistructured questionnaire. When analysing the interaction of different levels of administration and decision making, we are using data that consists of the documents from different administrative levels and qualitative data from a focus group interview. The questionnaire reveals villagers' and second home owners' perceptions of how to develop the village and their willingness to participate in public activities and need for services.

The documents analysed were: I) The development plan for rural areas of Rovaniemi 2013-2020 (Rovaniemi 2014), II) The participation and influencing plan of Rovaniemi citizens 2013-2016 (Rovaniemi 2013), III) The development plan of the Communal District Committee of Sodankyläntie 


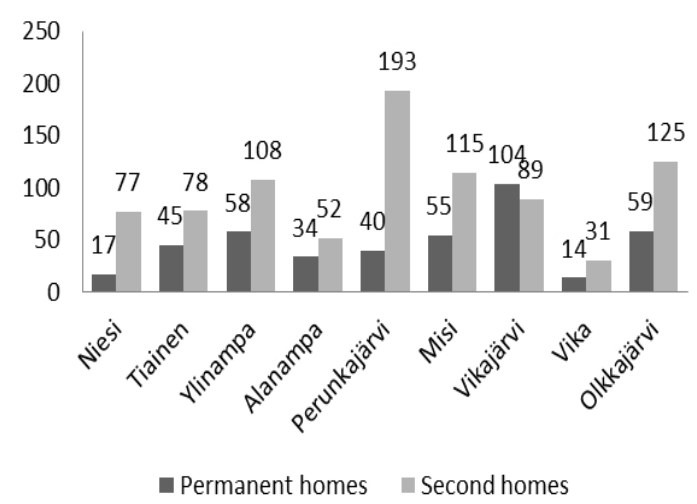

Fig. 2. Permanent and second homes in the villages of Sodankyläntie in 2012.

2013-2016 (Sodankyläntie 2013), and IV) The meeting minutes of the local Communal District Committee of Sodankyläntie (22.5.2013-4.6.2014 ten proceedings).

A focus group interview was organised in Perunkajärvi in September 2013. Overall, six permanent residents were represented in the focus group: three were previous second home owners, one second home owner, and one civil servant. In organising the discussions, we employed the semistructured "qualitative attitude approach" (cf. Vainio \& Paloniemi 2012). The method can be called "future-oriented focus groups". The main themes were: 1) participation in local planning and decision-making in the current situation, 2) local social and ecological changes in the future, and 3) local innovative means of participation in the future. In this focus group, participants were encouraged to reflect on the current situation of second home owner participation in Perunkajärvi, as well as their opportunity to develop structures and practices to participate and to develop the village in the future (Rinne et al. 2014). When inviting participants, we contacted municipal officials from Rovaniemi, and asked the municipality to set their representatives. In Perunkajärvi, locals and second home owners were invited by the chair of the village committee and, in addition, a public invitation was posted on the village noticeboard.

We also sent a questionnaire to the second home owners and permanent housing estates in Perunkajärvi in October 2013. The questionnaire was sent to 24 permanent real estate properties

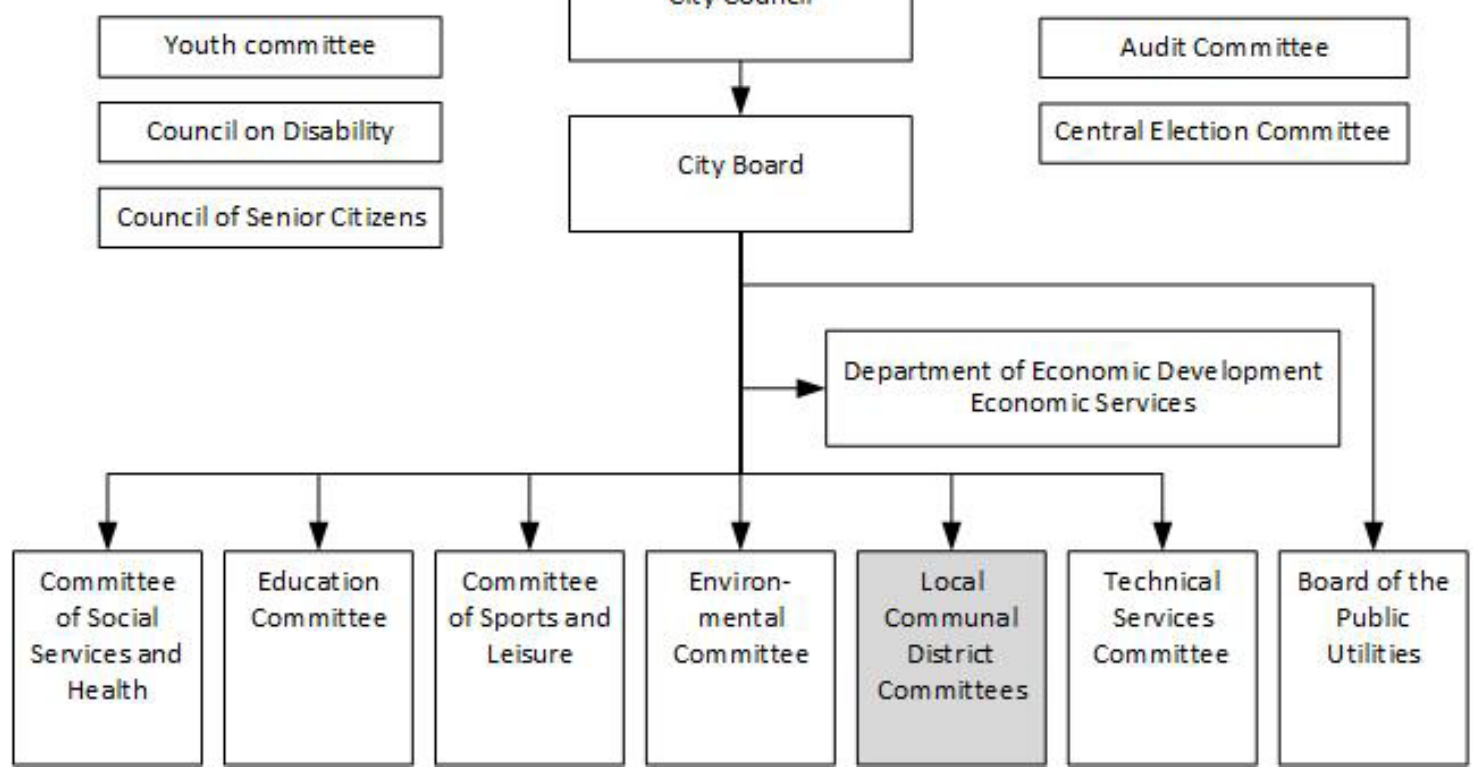

Fig. 3. Organisation of persons elected to a position of trust in Rovaniemi municipality. 
within the village and to 132 second home owners. According to the official statistics, there are altogether 40 permanent homes and 198 second homes, but the addresses provided by the municipality were not comprehensive, not up-to-date and they contained errors in owners' names and their permanent addresses while some people were deceased. Some of elderly permanent residents were in nursing homes or in hospital and the questionnaire was not sent to them. In the questionnaire, we asked, among other things, how second home owners and permanent residents take part in local associations, what issues (livelihoods, activities, organisations, village events, roads, etc.) in the village should be developed, what services they hope for. Furthermore, we enquired about the influence of second homes for village development. Altogether, 54 questionnaires were returned. The response rate was $34.6 \%$.

Our approach can be characterised as a mixedmethods approach. Quantitative questionnaires have been extensively used in previous secondhome research, and they have often focused on second home owner perspectives (Wallace et al. 2005). In the other semi-structured interviews participants included also second home and permanent residents as well as one civil servant of the municipality. Our exploration of second home owners' participation has the perspective of both permanent residents and second home owners.

\section{Analysis}

Documents were analysed using content analysis. The first step was counting mentions of second homes, second home owners, and summer cottages. The second step was analysing the context in which second homes or owners were mentioned. The third step was analysing the meaning of sections in which second home owners were mentioned and finding concepts to categorise these meanings. Also, the interaction of documents was analysed, for instance, how the local plans and minutes are considered in municipal plans and how these plans acknowledged second home owners.

The focus group discussions were analysed qualitatively (Maxwell 2005). We coded the content of the interviews by asking questions such as how interviewers talk about participation in second home contexts, and how they discuss the strengths and weaknesses of formal and informal participation opportunities (Rinne et al. 2014). 
The quantitative variables were analysed by conducting descriptive and bivariate statistics.

Three main categories were reduced from the data: the development of the village, participation and means of participation, and local services. Results are represented according to these three main categories and discussed in the context of community governance.

\section{Results}

\section{Development of village}

Municipal strategies and development plans guide the future actions of municipalities. Thus, if, for example, second homes or second home owners are mentioned in the local plans, this indicates that the issue is considered to be notable in the municipality.

In The development plan for rural areas of Rovaniemi (Rovaniemi 2014), the document defines the guidelines for the development of rural areas in the future, second homes (2) and the second home owners (3) are mentioned only five times while the need to plan second home areas was mentioned twice in the context of land use planning (Table 2). There are many second homes in the district of Sodankyläntie and, with the only exception represented by Vikajärvi, all the villages of the district have more second homes than permanent homes. However, second homes are not mentioned in the graph illustrating the most important issues affecting the district. In The development plan for rural areas of Rovaniemi (Rovaniemi 2014) and The development plan of the Communal District Committee of Sodankyläntie 20132016 (Sodankyläntie 2013), it is assumed that improved telecommunications could enhance remote work from second homes in the future, and increasing the time spent in second homes.

The development plan of the Communal District Committee of Sodankyläntie 2013-2016 (Sodankyläntie 2013) was based on The development plan for rural areas of Rovaniemi (Rovaniemi 2014). These plans were meant to implement The participation and influencing plan of Rovaniemi (Rovaniemi 2013). In this latter document, however, it was found that second home owners were not mentioned at all (Table 2). The development plan of the district committee and the plan for the development of rural areas had both been prepared in open public workshops. The agenda of the village workshops (Vikajärvi 2013) mentioned that second home owners should become involved because they were seen as a part of the participating and innovating community. There are nine villages in the area of Sodankyläntie: Alanampa, Misi, Niesi, Olkkajärvi, Perunkajärvi, Tiainen, Vika, and Vikajärvi. In the development plan of the CDC, second home

Table 2. Mentions of second homes, residents of second homes and second home areas in the communal plans and the minutes of the Communal District Committee.

\begin{tabular}{lcccc}
\hline & $\begin{array}{c}\text { Second } \\
\text { homes }\end{array}$ & $\begin{array}{c}\text { Second home } \\
\text { owners }\end{array}$ & $\begin{array}{c}\text { Second } \\
\text { home area }\end{array}$ & Total \\
\hline $\begin{array}{l}\text { The development plan for rural areas of Rovaniemi } \\
2013-2020 \text { (p. 47) }\end{array}$ & 2 & 3 & 2 & $\mathbf{7}$ \\
$\begin{array}{l}\text { The development plan of the Communal District } \\
\text { Committee of Sodankyläntie 2013-2016 (p. 28) }\end{array}$ & 6 & 2 & 0 & $\mathbf{8}$ \\
$\begin{array}{l}\text { The participation and influencing plan of Rovaniemi } \\
\text { citizens 2013-2016 (p.39) }\end{array}$ & 0 & 0 & 0 & $\mathbf{0}$ \\
$\begin{array}{l}\text { The minutes of local Communal District Committee } \\
\text { of Sodankyläntie (10 minutes) }\end{array}$ & 9 & 9 & 0 & $\mathbf{1 8}$ \\
\hline \multicolumn{1}{c}{ Total } & $\mathbf{8}$ & $\mathbf{5}$ & $\mathbf{2}$ & $\mathbf{3 3}$ \\
\hline
\end{tabular}


owners or second homes were mentioned altogether eight times (Table 2). It was found that second homes were mentioned six times and second home owners were mentioned once when the villages were described including their potential for recreation and spending free time. Second home owners were not mentioned as active actors in the villages, but rather in a background context. It was predicted that more second home owners would come to spend their leisure time and stay longer in the Rovaniemi district and also in Perunkajärvi in the future. However, second home owners have not been seen as co-operators in local public and business activities.

A similar tendency was observed in the minutes of the meetings of the CDC, as second home owners did not appear as active actors. The committee of Sodankyläntie had held ten official meetings until the summer of 2014, and second homes and second home residents were mentioned altogether 18 times (Table 2) in three of the meeting minutes (two in the autumn of 2013 and one in the summer of 2014). Second homes are mostly mentioned in the draft of the CDC development plan.

In the focus group discussion, the permanent residents especially were optimistic that the CDC could help to resolve some challenges facing the village, such as promoting funding for development projects, and improving traffic and telecommunications. During the discussion predictions were made regarding the CDC and their consideration of the remoteness and the large proportion of second homes in comparison to all real estate properties.

"We have 198 second homes and 40 permanent homes and the location of the village is special. These facts should be taken into account in the development plan of the Communal District Committee and especially the remoteness of the village." (ID: 7, villager, female)

The responses to the questionnaire revealed that the permanent residents wished for development of village activities, for example village events and the actions of associations. The most important development targets for second home owners were fishing and nature-based activities. Both permanent residents and second home owners stated that the development of telecommunications and traffic connections are important for the community, and all respondents in the group of permanent residents answered that these issues are very important to them.
In the questionnaire, $50 \%$ of the second home residents and almost $90 \%$ of the permanent residents agreed that the development of second homes in the village should be promoted for several reasons. For instance, the second home owners think that the village road would be better maintained if there were more second homes. In addition, they said that more second homes would support more services. Furthermore, an increasing number of second home residents would enliven the daily life of the small village. Those people who were against promoting second home housing in the village argued that there are already enough cottages and the village could become noisy. Permanent residents and second home owners who wanted to increase the number of second homes thought that it should be easier to get building permits for second homes. On the other hand, in the focus group, the civil servant from Rovaniemi mentioned that there will be no new shore plans in Perunkajärvi and only case-specific exceptional permits will be allowed. The land use plan of Rovaniemi states that areas for the development of new second homes should be located near the largest villages. Thus, the development of areas for second homes can be directed toward supporting the development of rural villages. Perunkajärvi is not close to any large village.

\section{Participation and means of participation}

During the focus group discussion, the villagers hoped that the CDC would help to arrange better public and private services and revitalise entrepreneurship. The only second home owner who took part in the focus group is an active member of the village association. Since the second home owners could not be formal representatives of the $\mathrm{CDC}$, the village association was the only place in which they could influence the district committee.

According to the survey, the second home owners were not active in any village associations (Table 3). Permanent residents seemed to be very active. However, it should be kept in mind that only a few permanent residents responded. Those who answered were probably the active persons, thus not representing the activity of all permanent residents.

One permanent resident of the village said that, despite the high number of second homes in the village, their owners were rarely seen in local meetings. The opinion of the permanent residents 
Table 3. The percentage of permanent residents and second home owners participating in village association activities (yes = participating, no $=$ not participating).

\begin{tabular}{lcc}
\hline & $\begin{array}{c}\text { Permanent } \\
\text { residents }\end{array}$ & $\begin{array}{c}\text { Second home } \\
\text { owners }\end{array}$ \\
\hline Yes & 87 & 18 \\
No & 13 & 82 \\
\hline
\end{tabular}

Table 4. Means and deviation of second home owners' contacts with permanent residents and other second home owners in Perunkajärvi. The scale is from 1 (not at all) to 5 (very often).

\begin{tabular}{lcc}
\hline & $\begin{array}{c}\text { Permanent } \\
\text { residents }\end{array}$ & $\begin{array}{c}\text { Other second } \\
\text { home owners }\end{array}$ \\
\hline $\mathrm{N}$ & 44 & 45 \\
Mean & 2.98 & 3.13 \\
Std. deviation & 1.067 & 1.014 \\
\hline
\end{tabular}

was that second home owners usually come to enjoy the peace of nature and are not eager to participate in communal actions or being members of local associations.

"In theory, second home owners have the same opportunities to participate and influence decision making as permanent residents but how is it possible to get them involved in practice?" (ID: 4, second home owner, male)

The focus group participants mentioned that, when local associations such as fishing and sports associations arrange competitions or events, they are usually for members only. Thus the right to participate is exclusive. In order to change the current approach, it was argued that events should instead be open for everyone. Openness would enhance communality, and it would be easier for new people to become acquainted with the villagers. This kind of action and working together would increase interaction.

Second home residents had slightly more contacts with other second home residents than with permanent residents of the village (Table 4, Fig.4), but the difference was statistically insignificant (paired samples test, sig. 0.291). There was a significant correlation between second home owners' contacts with permanent residents on the one hand and with other second home owners on the other hand; active second home owners were involved with both groups. The villagers had con- tact with other villagers and second home residents little more than "now and then" (average 3.25). Residents, part-time and permanent home owners who have broader social relations also actively participate in local meetings and decision making.

The participation and influencing plan of citizens of Rovaniemi 2013-2016 (Rovaniemi 2013) aims to activate the residents and involve them in the communal decision making. The document has been formally adopted by the municipality of Rovaniemi. It states that CDCs stand for representative direct democracy and enhance the participation and influence of inhabitants. It also notes that residents and village associations represent direct democracy that is the traditional base for the action of residents. Still, second home owners are not mentioned in this document. The CDC have had the possibility to make a statement about the draft of the participation and influencing plan, but they had not suggested including second home owners in the plan.

Although CDCs are a part of the official communal decision making system, representatives of committees are elected by public village meetings. This procedure is different from the elections of other boards of the municipality. This election system will most likely be changed in the future if the experiment of CDCs continues. It is possible that local district committee members will be elected within municipal elections. For the time being, the 
representative of a village has to be a permanent resident of that village. Therefore, the only opportunity for participation by second home owners is indirectly via the village association.

"The Communal District Committee increases the potential influence of second home owners because the formal representative of the village on the committee can also be their messenger. If there is an important issue concerning the village, we can convene a village meeting and hear villagers' opinions. After that, we can bring them to the agenda of the Communal District Committee. But it is very difficult to persuade second home owners to attend village meetings, though we have asked them." (ID: 1, villager, male)

The low level of second home owner participation is not entirely rooted in the limited ways for them to influence policy. The focus group revealed that many second home owners had not taken part in association meetings, as they prefer contacts with other second home owners instead. When spending their leisure time, they did not want to be active citizens. Second home owners relaxed by eating, reading and spending leisure time in the countryside.

\section{Local services and activities}

As mentioned before, the village of Perunkajärvi does not provide many local services. In addition to this, the villagers who are active in developing the village were asked whether they know what kind of services might be preferred by the second home owners. It was found that most of the permanent residents do not know what kind of services second home owners prefer to have. During the summer 2014 meeting it was also found that the service needs of second home owners have been recognised by the city council representatives. These needs are presently ascertained in all the villages of Rovaniemi.

One participant said "Second home owners will need, before long, services when they are staying longer and getting older." (ID: 7, villager, female) At once another lady added: "What services? We do not have any here." (ID: 6, villager, female).

According to the questionnaire, when second home owners were choosing the area in which to build or to buy a second home, the provision of services was not a very important factor when considering (Table 5) to buy real estate in Perunkajärvi. The most important factor was nature and also the leisure time activities (Fig. 5).

There was a discussion in the focus group concerning a future plan to provide a service bus that could provide multi-services such as health care assistance and a library. For instance, the villagers agreed that the bus could also provide services to second home owners. Also in the questionnaire, the permanent residents listed a service bus as a service that is needed in all villages. In addition, "a village caretaker" and better internet connection were mentioned. Services required by the second home owners included a grocery shop or mobile shop bus, and some of them desired cleaning help and health services. The need for cleaning and health services is likely to increase; this can be related to the fact that $60 \%$ of the second home owner respondents are retired and elderly people.

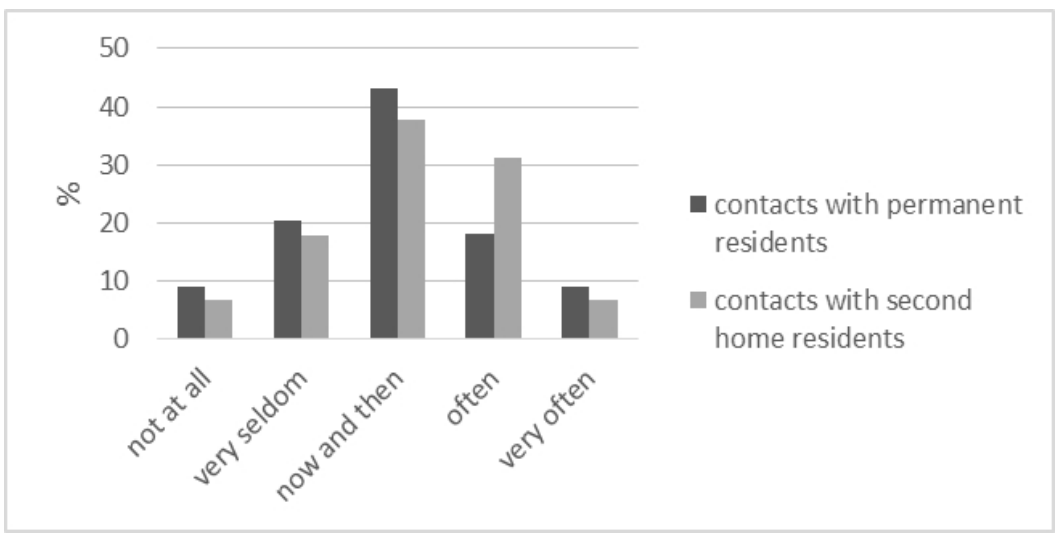

Fig. 4. Second home owners' contacts with permanent residents and the other second home owners in Perunkajärvi. 


\begin{tabular}{lccc}
\hline & Nature & $\begin{array}{c}\text { Leisure } \\
\text { activities }\end{array}$ & Services \\
\hline $\mathrm{N}$ & 42 & 42 & 43 \\
Mean & 4.12 & 3.24 & 1.53 \\
Std. deviation & 0.942 & 1.322 & 0.827 \\
\hline
\end{tabular}

Table 5. The importance of nature, leisure activities and services for second home owners when choosing Perunkajärvi. Showing $\mathrm{N}$, mean, and Std. deviation. The scale is from 1 (not important) to 5 (very important).

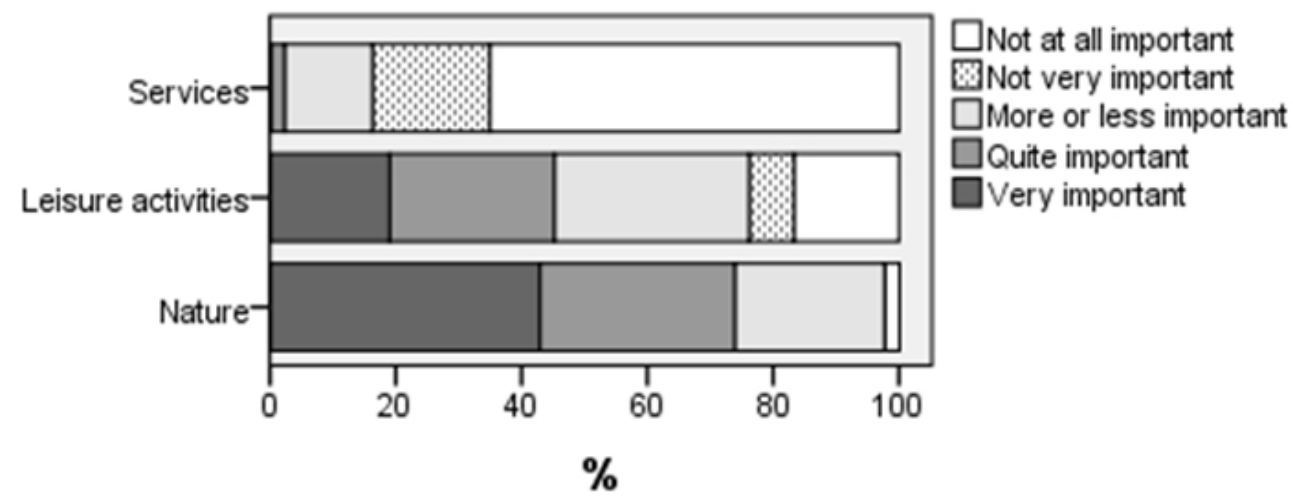

Fig. 5. Second home owners' evaluation of reasons why they chose the Perunkajärvi area: nature, leisure activities and services.

According to the questionnaire, the second home owners did not use local services very much. The most used services were the snow removal from private roads and the purchasing firewood. A slight interest was shown in local nature destinations and local events.

\section{Discussion}

In this article, we have studied how a new communal decision making model can improve resident participation and especially second home owner participation in the development of villages. Although the new local decision making level is only represented by the $\mathrm{CDC}$, the entire structure of decision making is difficult to change. Moreover, structural policy changes should be developed through inclusive political strategies (Pemberton \& Goodwin 2010). To this end, the municipal strategies of Rovaniemi should consider second home owners as being among the actors of the decision making process. At present, they may have indirect influence via village associations. Thus, our findings support similar notions by Hall and Müller (2004) that the committees are not formally promoting second home owners' participation.

In our case, we found that second home owners have not been active in taking part in the actions or meetings of village associations, so that the indirect influence via village association is insufficient to transfer their wishes and needs to the CDC. This challenge has also been identified by Lipkina and Hall (2014) in their study of second home owners' willingness to take part in communal decision making or participate in local associations. The Perunkajärvi villagers' hope to have more actively participating second home owners is in contrast to the second homer owners' own desire on how to spend their leisure time. Participation is seen as an indication of social inclusion and engagement; however, the decision of whether or not to participate, based on self-defined limits, is rational (Hayward et al. 2004; Shortall 2008).

Nylander and Leppänen (2006) stated that the opportunities for second home owners to influ- 
ence the municipality are generally insufficient at this time; however, if second home owners are active, they have the chance to have their opinions heard. Moreover, few second home owners, in Perunkajärvi, who had actively taken part in local associations, had a key role in building contacts between second home owners and villagers. Greater inclusion and participation in local associations might enhance municipal democracy, as Nordin and Marjavaara (2012) argued that participation in local association life, among locals and second home owners, is particularly important from a democratic perspective.

As second home owners can be seen as potential resources for the village, it would also be important to facilitate their participation in the CDC. They can contribute, not only economically, but, also with their knowledge (Robertsson \& Marjavaara 2014). Second home owners are frequently elderly people, often near retirement, and they represent the middle class or wealthy component of the population (Mottiar \& Quinn 2003; Strandell \& Hall 2015), so they have time and knowhow. On the other hand, the stereotype of the traditional second home owner is currently being challenged by heterogeneous second home ownership (Rinne et al. 2015). This encourages us to consider the wide range of perspectives, opinions and expertise that this diverse group of second home owners may have.

Our results showed that in order to identify local development issues and needs for both residents and second home owners, it is important to activate the participation and interaction of second home owners and permanent inhabitants. Barnett (2014) has suggested that second home owners' engagement in host communities needs to be active. It has been noted that the interest may; however, increase significantly and rapidly, when issues having a direct impact on the environment surrounding the second home are involved, such as new constructions or changes in land use (Mottiar \& Quinn 2003; Rinne et al. 2015). In our case, both villagers and second home owners were not satisfied with the Internet connection. Therefore, this issue could be such a shared interest that increases interaction between villagers and second home owners. In the municipal development plan of Rovaniemi, telecommunications development was seen as important, as it might increase the time spent in second homes. Hiltunen and Rehunen (2014) have argued that distance work is becoming more popular as, in an increasing num- ber of second homes, the standard of amenities is high and Internet access is available. Though the municipal plan emphasises the importance of telecommunications, they have not been developed in practice. To satisfy locals' wants, there is a need to develop interaction with municipal authors and local actors, both residents and second home owners. This might happen if opportunities for participation are opened and if the perspectives of second home owners are constructively integrated into the dialogue with local actors.

Various models have been used to describe decisional methods. In that of the district committee, attempts to downscale decision making including local rural areas. This model is similar to a multilevel governance in which 'top-down' approaches accommodate those that are 'bottom-up'. The capacities of localities to act in their own interest is supported by the opportunities presented in a multi-level governance structure and can be developed in ways that include all relevant stakeholders taking part in decision making (Sullivan et al. 2004). Tough village and residents' associations have been seen to provide formal channels of participation to second home owners (Rinne et al. 2015). The associations do not have a formal position in the municipal decision-making process, and therefore, their roles should be made explicit.

We noticed that second home owners prefer remote rural areas, as they aim to improve the quality of their everyday life through the amenities of nature and a peaceful environment. Overall in Finland, it seems that among second home owners and users, free-time spent at the cottage is mainly used for relaxing and placing mental distance from working life (Hiltunen \& Rehunen 2014). Therefore, nature is important as a concrete platform for different activities; both use-oriented activities, such as fishing, picking berries and mushrooms, and recreation-oriented activities, such as walking in the forest, swimming, and enjoying a sauna (Vepsäläinen \& Pitkänen 2010; Pitkänen et al. 2011). Farstad and Rye (2013) found that second home owners have a stronger interest in preserving natural amenities than in rural development.

In rural areas, such as Perunkajärvi, both permanent and second home inhabitants are increasingly elderly people, and second home owners stay in their second homes longer than before. These two trends, together, raise the demand for local services, especially health and recreation services (Jauhiainen 2009; Müller \& Marjavaara 2012; Osbaldiston et al. 2015). Considering the 
population structure and the long distances between villages, the major challenge for municipalities is to provide services, whether they are public or private. Analysing the implementation of the Italian social services reform, Bifulco and Centemeri (2008) noted the importance of third sector participation in the local welfare system. The use or disuse of services and space can also indicate the extent of involvement in the local community, even though the use of services, by second home owners, is usually viewed from the perspective of economic contribution to the local economy (Lipkina \& Hall 2014). Thus, if only the local elite are represented in local government councils, they might not consider wider public needs and prefer decisions favourable to themselves (Blair 2000). As Reddel and Woolcock (2004) stated, the relationship between representative and participatory governance might be problematic and it is important to make the link more explicit and transparent. We consider that this may promote participation by second home owners and help to create a new means of participation. Small councils bring decision makers into direct contact with those people affected by their decisions, and thus, reduce the propensity for large bureaucracies to 'depersonalise' policy outcomes, with positive results for efficient delivery (Dollery \& Johnson 2005).

\section{Conclusions}

In this study, we found that permanent residents of villages perceive second home owners as not being particularly interested in participating in the planning and decision making related to local issues. On the other hand, permanent residents seem to look to second home owners for new ideas concerning how to develop the services that second home owners need, as permanent residents are not aware of second home owners' needs and priorities. The general perception is that the greater the time people live in the village, the greater the pressure for municipalities to arrange services for all residents.

Perhaps, it is typical that relatively few vacationers, staying in second homes, are active and involved in local events. It is a major challenge to find inspiring means to encourage second home owners to be active and participatory. The topics that are of interest to both permanent and parttime residents, such as fishing, might be a good starting point for establishing collaboration. Collaboration and relationship building may reduce potential conflicts.

According to the municipal documents and plans, it seems that second home owners are not seen, at least in this case, to be a significant group of inhabitants, in terms of local decision making. Hence, local-level communal decision making does not necessarily promote the participation of second home residents. The experimental phase of decision making follows old decision making structures, which are insufficient at taking into account multi-placed living. Thus, the municipal authorities should recognise the existence and importance of second home owners, in their area this can be done by better acknowledging their existence and having their specific needs and priorities reflected in municipal plans and strategies, as well as by offering them more financial resources and employing innovative means to encourage participation. Local governance arrangements, which already integrate second home owners in planning and decision making processes, should be further studied in detail and new practices should be developed.

\section{ACKNOWLEDGEMENTS}

This work was supported by the Academy of Finland [Project nr. SA255424]. We would also like to thank Vesa Nivala for preparing the map of the case study area.

\section{REFERENCES}

Adams D \& Hess M 2001. Community in public policy: fad or foundation. Australian Journal of Public Administration 60: 2, 13-23. http://dx.doi.org/10.1111/1467-8500.00205.

Asikainen J 2011. Strateginen päätöksentekokyky ja toimeenpanokyky itsehallinnon toteuttajana erilaisissa toimintaympäristöissä. In Haveri A, Stenvall J \& Majoinen K (ed). Kunnallisen itsehallinnon peruskivet [Cornerstones of municipal self-government], 316-321. Acta Publications No. 224. The Association of Finnish Local and Regional Authorities and The Finnish Association of Local Government Studies, Helsinki. (in Finnish, introduction in English)

Barnett J 2014. Host community perceptions of the contributions of second homes. Annals of Leisure Research 17: 1, 10-26.

http://dx.doi.org/10.1080/11745398.2014.886156. 
Bifulco L \& Centemeri L 2008. Governance and participation in local welfare: the case of Italian Piani di Zona. Social Policy \& Administration 42: 3, 211-227. http://dx.doi.org/10.1111/j.1467-9515.2007.00593.x.

Blair $\mathrm{H}$ 2000. Participation and accountability at the periphery: democratic local governance in six countries. World Development 28: 1, 212-39. http://dx.doi.org/10.1016/S0305-750X(99)00109-6.

Dollery B \& Johnson A 2005. Enhancing efficiency in Australian local government: an evaluation of alternative models of municipal governance. Urban Policy and Research 23: 1, 73-85.

http://dx.doi.org/10.1080/0811114042000335278.

Farstad M 2013. Local residents' valuation of second home owners' presence in a sparsely inhabited area. Scandinavian Journal of Hospitality and Tourism 13: 4, 317-331.

http://dx.doi.org/10.1080/15022250.2013.863062.

Farstad M \& Rye JF 2013. Second home owners, locals and their perspectives on rural development. Journal of Rural Studies 30, 41-51. http://dx.doi.org/10.1016/j.jrurstud.2012.11.007.

Goss S 2001. Making local governance work. Networks, relationships and the management of change. Government beyond the centre. Palgrave, Basingstoke.

Hall CM 2015. Second homes planning, policy and governance. Journal of Policy Research in Tourism, Leisure and Events 7: 1, 1-14. http://dx.doi.org/10.1080/19407963.2014.964251.

Hall CM \& Müller DK 2004. Introduction: second homes, curse or blessing? Revisited. In Hall CM \& Müller DK (eds). Tourism, mobility and second homes. Between elite landscape and common ground, 3-14. Channelview, Clevedon.

Hall CM, Müller DK \& Saarinen J 2009. Nordic tourism. Issues and cases. Channelview, Bristol.

Halme E \& Kuukasjärvi L 2010. Uusi kunta vai kuntaliitos - kuntalaisen itsehallinto. Kunnallisalan kehittämissäätiön Polemia-sarjan julkaisu nro 76. Pole-Kuntatieto Oy, Helsinki. (in Finnish)

Haveri A, Stenvall J \& Majoinen K 2011. Introduction. In Haveri A, Stenvall J \& Majoinen K (eds). Kunnallisen itsehallinnon peruskivet [Cornerstones of municipal self-government], 26-35. Acta Publications No. 224, Helsinki.

Hayward C, Simpson L \& Wood L 2004. Still left out in the cold: Problematising participatory research and development. Sociologia Ruralis 44: 1, 95-109. http://dx.doi.org/10.1111/j.1467-9523.2004.00264.x.

Hess M \& Adams D 2007. Innovation in public management: the role and function of community knowledge. The Innovation Journal: The Public Sector Innovation Journal 12: 1, article 2. <http:// www.innovation.cc/volumes-issues/hess_adams_ innovate_public_manage8final.pdf> 15.03.2015.

Hiltunen MJ 2007. Environmental impacts of rural second home tourism - case Lakedistrict in Finland. Scandinavian Journal of Hospitality and Tourism 7: 3, 243-265. http://dx.doi.org/10.1080/15022250701312335.

Hiltunen MJ, Pitkänen K, Vepsäläinen M \& Hall CM 2013. Second home tourism in Finland: current trends and eco-social impacts. In Roca Z (ed). Second homes in Europe: from lifestyle to policy issues, 165-198. Ashgate, Aldershot, UK.

Hiltunen M \& Rehunen A 2014. Second home mobility in Finland: patterns, practices and relations of leisure oriented mobile lifestyle. Fennia 192: 1, 1-22. http://dx.doi.org/10.11143/8384.

Jauhiainen JS 2009. Will the retiring baby boomers return to rural periphery? Journal of Rural Studies 25: 1, 25-34.

http://dx.doi.org/10.1016/j.jrurstud.2008.05.001.

Jordan EJ, Vogt CA, Kruger LE \& Grewe N 2013. The interplay of governance, power and citizen participation in community tourism planning. Journal of Policy Research in Tourism, Leisure and Events 5: 3, 270-288.

http://dx.doi.org/10.1080/1907963.2013.789354.

Kallio KP \& Bäcklund P 2012. Oletettu alueellisuus, kuviteltu osallisuus - tilalliset sidokset julkishallinnon lapsi ja nuorisopoliittisessa retoriikassa. [Expected locality, imagined commitment - spatial situatedness in public administration child and youth policy rhetoric]. Terra 123: 4, 245-258.

Kaltenborn BRP, Andersen O, Nellemann C, Bjerke T \& Thrane C 2008. Resident attitudes towards mountain second-home tourism development in Norway: the effects of environmental attitudes. Journal of Sustainable Tourism 16: 6, 664-680. http://dx.doi.org/10.1080/09669580802159685.

Kauppinen M 2004. Väestömuutos tulee - onko kuntasi valmis? Kunnallistieteellinen aikakauskirja 31: 1, 16-35. (in Finnish, abstract in English)

Kelly G \& Hosking K 2008. Nonpermanent residents, place attachment, and "sea change" communities. Environment and Behaviour 40: 4, 575-594. http://dx.doi.org/10.1177/0013916507302246.

van Laar S, Cottyn I, Donaldson R, Zoomers A \& Ferreira S 2014. 'Living apart together' in Franschhock, South Africa. The implications of home development for equitable and sustainable development. In Janoschka M \& Haas H (eds). Contested spatialities, lifestyle migration and residential tourism, 190-203. Routledge, London.

Lipkina O \& Hall CM 2014. Russian second home owners in Eastern Finland: involvement in the local community. In Janoschka M \& Haas H (eds). Contested spatialities of lifestyle migration, 158173. Routledge, London.

Marjavaara R 2007. The displacement myth: second home tourism in the Stockholm archipelago. Tourism Geographies 9: 3, 296-317. http://dx.doi.org/10.1080/14616680701422848.

Marjavaara R 2008. Second home tourism: the root to displacement in Sweden? GERUM2008:1. Umeå University, Umeå.

Maxwell J A 2005. Qualitative research design: an interactive approach. Applied social research methods series: 41. Sage Publications, Thousand Oaks, CA. 
Ministry of Finance 1995. Local Government Act (365/1995). <https://www.finlex.fi/en/laki/kaannokset/1995/en 19950365.pdf> 15.04.2015

Ministry of Justice 1999. Constitution of Finland (731/1999). Section 121. <http://www.finlex.fi/ en/laki/kaannokset/1999/en 19990731.pdf> 15.04.2015

Mottiar Z \& Quinn B 2003. Shaping leisure/tourism place - the role of holiday home owners: a case study of Courtown, Co. Wexford, Ireland. Leisure Studies 22: 2, 109-127.

Müller DK 2006. The attractiveness of second home areas in Sweden: a quantitative analysis. Current Issues in Tourism 9: 4-5, 335-350.

Müller DK \& Marjavaara R 2012. From second home to primary residence: migration towards recreational properties in Sweden 1991-2005. Tijdschrift voor Economische en Sociale Geografie 103: 1, 53-68.

http://dx.doi.org/10.1111/j.1467-9663.2011.00674.x.

Möttönen S 2011. Kunnallisen itsehallinnon merkitys ja uudistuminen muuttuvassa toimintaympäristössä. In Haveri A, Stenvall J \& Majoinen $\mathrm{K}$ (eds). Kunnallisen itsehallinnon peruskivet, 63-84. Kuntaliitto, Helsinki.

de Nazaré Oliveira Roca M, Roca Z, Oliveira JA \& Costa L 2014. Second home expansion in Portugal. In Janoschka M \& Haas H (eds). Contested spatialities, lifestyle migration and residential tourism, 24-142. Routledge, London.

Nordin U \& Marjavaara R 2012. The local non-locals: second home owners associational engagement in Sweden. Tourism Preliminary communication 60: 3, 293-305.

Nylander M \& Leppänen J 2006. Vapaa-ajan asukkaiden osallistuminen kuntien päätöksentekoon. Sisäasiainministeriön julkaisu 14. Saaristoasiain neuvottelukunta, Suunnittelukeskus Oy, Helsinki.

Osbaldiston N, Picken \& Duffy 2015. Characteristics and future intentions of second homeowners: a case study from Eastern Victoria, Australia. Journal of Policy Research in Tourism, Leisure and Events 7: 1, 62-76.

http://dx.doi.org/10.1080/19407963.2014.934689.

OSF [Official Statistics of Finland] 2012. Buildings and free-time residences [e-publication]. Statistics Finland, Helsinki. <http://www.tilastokeskus.fi/ til/rakke/2012/rakke_2012_2013-05-24_ tie_001_en.html>04.06.2013.

Overåg K \& Berg NG 2011. Second homes, rurality and contested space in Eastern Norway. Tourism Geographies: An International Journal of Tourism Space, Place and Environment 13: 3, 417-442. http://dx.doi.org/10.1080/14616688.2011.570778.

Paris C 2008. Re-positioning second homes within housing studies: household investment, gentrification, multiple residence, mobility and hyper-consumption. Housing, Theory and Society 26, 292-310. http://dx.doi.org/10.1080/14036090802300392.

Pemberton S \& Goodwin M 2010. Rethinking the changing structures of rural local government - statepower, rural politics and local political strategies? Journal of Rural Studies 26, 272-283. http://dx.doi.org/10.1016/j.jrurstud.2009.12.005.

Pihlaja R \& Sanberg S 2012. Alueellista demokratiaa? Lähidemokratian toimintamallit Suomen kunnissa. Valtiovarainministeriön julkaisuja 27/2012 [Ministry of Finance publications 27/2012]. Suomen Yliopistopaino Oy - Juvenes Print, Tampere. (in Finnish, abstract in English)

Pitkänen K, Puhakka R \& Sawatzky M 2011. The role of nature in the place meanings and practices of cottage owners in northern environments. Norsk Geografisk Tidsskrift - Norwegian Journal of Geography 65: 3, 175-187.

http://dx.doi.org/10.1080/00291951.2011.598236.

Reddel T 2002. Beyond participation, hierarchies, management and markets: 'new' governance and place polities. Australian Journal of Public Administration 61: 1, 50-63.

http://dx.doi.org/10.1111/1467-8500.00258.

Reddel T \& Woolcock G 2004. From consultation to participatory governance? Acritical review of citizen engagement strategies in Queensland. Australian Journal of Public Administration 63: 3, 75-87. http://dx.doi.org/10.1111/j.1467-8500.2004.00392.x.

Rinne J, Kietäväinen A, Tuulentie S \& Paloniemi R 2014. Governing second-homes $\neg$ - a study of policy coherence of four policy areas in Finland. Tourism Review International 18: 3, 223-236. http://dx.doi.org/10.3727/154427214X14101901317318.

Rinne J, Paloniemi R, Tuulentie S \& Kietäväinen A 2015. Participation of second home users in local planning and decision-making. A study of three cottage-rich locations in Finland. Journal of Policy Research in Tourism, Leisure and Events 7: 1, 98-114.

http://dx.doi.org/10.1080/19407963.2014.909818.

Robertsson L \& Marjavaara R 2015. The seasonal buzz: knowledge transfer in a temporary setting. Tourism Planning \& Development 12: 3, 251-265. http://dx.doi.org/10.1080/21568316.2014.947437.

Rovaniemi 2013. Asukkaiden osallisuuden ja vaikuttamisen kehittämisohjelma 2013-2016 [The participation and influence plan of Rovaniemi citizens 2013-2016]. <http://www.rovaniemi.fil loader.aspx?id=f4a09790-beab-481a-beb615a8682eb469>15.04.2015. (in Finnish)

Rovaniemi 2014. Rovaniemen maaseudun kehittämisohjelam 2013-2020 [The development plan for rural areas of Rovaniemi 2013-2020]. <http:// www.rovaniemi.fi/loader.aspx?id=7c392c4bad4e-4d24-9fc2-25ca9fd6488f> 15.04.2015. (in Finnish)

Rovaniemi 2016. Rovaniemen toimintaympäristön tilastot 2016. <http://www.rovaniemi.fi/loader. aspx?id=a23e710c-8933-4672-b1e0-c63a45e$d 7 f 34>15.05 .2016$. (in Finnish)

Rye JF 2011. Conflicts and contestations. Rural populations' perspectives on the second homes phenomenon. Journal of Rural Studies 27: 3, 263-274. http://dx.doi.org/10.1016/j.jrurstud.2011.03.005. 
Ryynänen A \& Uoti A 2009. Kunnallinen itsehallinto ja uusi hallintotapa. In Karppi I \& Sinervo L-M (eds). Governance: uuden hallintatavan jäsentyminen, 212-236. Tampereen yliopisto. Kauppa- ja hallintotieteiden tiedekunta, Tampere. (in Finnish)

Salminen A 2008. Evaluating the new governance of the welfare state in Finland. International Journal of Public Administration 31: 10-11, 1242-1258. http://dx.doi.org/10.1080/01900690801973352.

Shortall S 2008. Are rural development programme socially inclusive? Social inclusion, civic engagement, participation, and social capital: exploring the differences. Journal of Rural Studies 24: 4, 450-457. http://dx.doi.org/10.1016/j.jrurstud.2008.01.001.

Sjöblom S 2002. Kuntalainen vaikuttajana. In PekolaSjöblom M, Helander V \& Sjöblom S (eds). Kuntalaisen monet roolit, 77-95. Suomen Kuntaliitto, Helsinki. (in Finnish)

Sodankyläntie 2013. Sodankyläntien aluelautakunnan kehittämissuunnitelma 2013-2016 [The development plan of the Communal District Committee of Sodankyläntie 2013-2016]. 11.12.2014. (in Finnish)

Strandell A \& Hall CM 2015. Impact of the residential environment on second home use in Finland testing the compensation hypothesis. Landscape and Urban Planning 133, 12-23.

http://dx.doi.org/10.1016/j.landurbplan.2014.09.011.

Sullivan H, Knops A, Barnes M \& Newman J 2004. Central-local relations in an era of multi-level governance: the case public participation policy in England, 1997-2001. Local Government Studies 30: 2, 245-265.

http://dx.doi.org/10.1080/0300393042000267263.

Suomen kuntaliitto 2016. Kaupunkien ja kuntien lukumäärä. <http://www.kunnat.net/fi/tietopankit/ tilastot/aluejaot/kuntien-lukumaara/Sivut/default. aspx> 02.05.2016.

Vainio A \& Paloniemi R 2012. Forest owners and power: a Foucauldian study on Finnish forest policy. Forest Policy and Economics 21, 118-125. http://dx.doi.org/10.1016/j.forpol.2012.02.008.

Vepsäläinen M \& Pitkänen K 2010. Second home countryside. Representations of the rural in Finnish popular discourses. Journal of Rural Studies 26: 2, 194-204.

http://dx.doi.org/10.1016/j.jrurstud.2009.07.002.

Vikajärvi 2013. Maaseudun kehittämisohjelma Vikajärvi. Maaseudun kehittämisohjelman avoimet kyläkokoukset. Sodankyläntien suunta Vikajärvi <http: //www.rovaniemi.fi/loader. aspx?id=5d12dc96-d185-4e57-a55d-e997e$a b 25455>20.3 .2013$. (in Finnish)

Wallace A, Bevan M, Croucher K, Jacson K, O'Malley L \& Orton V 2005. The impact of empty, second and holiday homes on the sustainability of rural communities - a systematic literature review. The Centre for Housing Policy, University of York, York. 